\title{
Gender differences in tobacco use in rural Madagascar: Fresh perspectives from a 2019 health survey
}

Tatsumi Yanaba', Kyle Robinson ${ }^{1}$

\section{Dear Editor,}

Since the 2005 WHO Framework Convention on Tobacco Control set guidelines to reduce tobacco use worldwide, progress reducing tobacco use has varied widely by country. Low-and-middle-income countries (LMICs) in Africa and the Eastern Mediterranean have seen a rapid rise in tobacco use ${ }^{1}$. Notably, the 2008 Demographic Health Survey (DHS) demonstrated an exceptionally high tobacco use rate in Madagascar, $48.9 \%$ for men and $10.3 \%$ for women ${ }^{2}$. The high rate of tobacco use is especially concerning considering that premature death rates from stroke and ischemic heart diseases, conditions associated with tobacco use, have risen rapidly in Madagascar in recent decades ${ }^{3}$.

The 2008 DHS revealed that individuals of both sexes residing in rural areas were more likely to use smokeless tobacco products - namely chewing and snuff tobacco - than individuals residing in urban areas ${ }^{4}$. To better understand the factors contributing to this discrepancy in tobacco use patterns, we conducted a health survey in rural Northern Madagascar.

We collected data through a voluntary survey of visitors $(\mathrm{N}=338)$ to a nonprofit health clinic between June and July 2019 in the village of Maventibao, five hours by dirt road from the nearest city, Antsiranana. This Mayo Clinic IRB and Antsiranana Ministry of Health approved survey asked for participants' village, age, sex (female or male), current tobacco use (smoking, chewing, and snuff), number of cigarettes smoked per day (if a smoker), and occupational status (farmer, miner, other manual services, non-manual service, or unemployed). Occupational status categories aligned with prior research ${ }^{4,5}$. Table 1 summarizes demographics by sex, occupation, and tobacco use.

A greater proportion of men used tobacco than women ( $60.84 \%$ vs $22.05 \%$, $\mathrm{p}<0.001)$. Furthermore, men were more likely to smoke tobacco than women $(52.45 \%$ vs $8.72 \%, \mathrm{p}<0.001)$. There was a significant difference in occupational status between gender, with a larger proportion of women in farming or unemployed, and more men working in other manual services $(\mathrm{p}<0.005)$.

The rate of male tobacco use was nearly double that reported by the 2008 DHS $^{2}$. This rate may imply a regional anomaly in rural tobacco use or a significant shift in tobacco use patterns within the previous decade. Despite Madagascar having the highest federal tax rate on commercial tobacco products in Sub-Saharan Africa (80.4\%), this increase persists ${ }^{6}$. Locally grown tobacco and hand-rolled cigarettes are widely sold and consumed in rural Madagascar, possibly to evade high taxation rates ${ }^{5}$. It would be valuable to investigate further how the utilization of untaxed locally grown tobacco products relates to changes in taxation policies.

Among females, the predominance of smokeless tobacco use $(12.82 \%)$ over cigarette use $(8.72 \%)$ was consistent with the $2008 \mathrm{DHS}^{2}$. Social factors driving
AFFILIATION

1 Mada Clinics, Mayo Clinic School of Medicine, Rochester, United States

CORRESPONDENCE TO

Kyle Robinson. Mada Clinics, Mayo Clinic School of Medicine, Rochester, MN 55905, United States. Email: Robinson.Kyle@ mayo.edu ORCID ID: https://orcid. org/0000-0003-3934-3206

KEYWORDS

tobacco, Madagascar, gender, rural, smoking, occupation

Received: 16 May 2021 Accepted: 26 May 2021 
Table 1. Gender, occupation status, and tobacco use of participants $(\mathrm{N}=338)$

\begin{tabular}{|c|c|c|c|}
\hline \multirow{2}{*}{$\begin{array}{l}\text { Occupation status } \\
\text { Male participants }(n=143)\end{array}$} & \multicolumn{3}{|c|}{ Tobacco use } \\
\hline & $\begin{array}{l}\text { Smoking } \\
\text { tobacco } \\
(n=75)\end{array}$ & $\begin{array}{l}\text { Smokeless } \\
\text { tobacco } \\
(n=16)\end{array}$ & $\begin{array}{l}\text { No tobacce } \\
\quad(n=56)\end{array}$ \\
\hline Farming (43) & 12 & 5 & 14 \\
\hline Mining (38) & 5 & 0 & 10 \\
\hline Other manual service* $(13)$ & 0 & 1 & 4 \\
\hline Non-manual service ${ }^{* *}(20)$ & 3 & 2 & 3 \\
\hline Unemployed (1) & 0 & 1 & 0 \\
\hline NA (102) & 55 & 7 & 25 \\
\hline Female participants $(n=195)$ & $\begin{array}{l}\text { Smoking } \\
\text { tobacco } \\
(n=17)\end{array}$ & $\begin{array}{c}\text { Smokeless } \\
\text { tobacco } \\
(n=25)\end{array}$ & $\begin{array}{c}\text { No } \\
\text { tobacco } \\
(n=153)\end{array}$ \\
\hline Farming (69) & 7 & 9 & 53 \\
\hline Mining (40) & 3 & 6 & 29 \\
\hline Other manual service* $(6)$ & 0 & 0 & 5 \\
\hline Non-manual service ${ }^{* *}(28)$ & 0 & 0 & 20 \\
\hline Unemployed (16) & 2 & 1 & 13 \\
\hline NA (124) & 5 & 9 & 32 \\
\hline
\end{tabular}

${ }^{*}$ Other manual services include gardener, construction worker, and herder ${ }^{* *}$ Nonmanual services include seamstress, store worker, nurse, teacher, cook, and businessman. NA: not available.

female use of smokeless tobacco in Madagascar may exist early in adolescence resulting from adult role models or peer pressure at school, as suggested by recent research ${ }^{7}$. Future studies may explore how gender differences in occupation affect exposure to social factors influencing tobacco use and product choice.

\section{REFERENCES}

1. Bilano V, Gilmour S, Moffiet T, et al. Global trends and projections for tobacco use, 1990-2025: an analysis of smoking indicators from the WHO Comprehensive Information Systems for Tobacco Control. Lancet. 2015;385(9972):966976. doi:10.1016/S0140-6736(15)60264-1

2. Sreeramareddy CT, Pradhan PM, Sin S. Prevalence, distribution, and social determinants of tobacco use in 30 sub-Saharan African countries. BMC Med. 2014;12:243. doi:10.1186/s12916-014-0243-x

3. Institute for Health Metrics and Evaluation. GBD Profile: Madagascar. 2010. Accessed May 16, 2021. https://www. healthdata.org/sites/default/files/files/country_profiles/ GBD/ihme_gbd_country_report_madagascar.pdf

4. Mamudu HM, John RM, Veeranki SP, Ouma AE. The odd man out in Sub-Saharan Africa: understanding the tobacco use prevalence in Madagascar. BMC Public Health. 2013;13(1):856. doi:10.1186/1471-2458-13-856

5. Blecher E, Liber AC, Chaussard M, Fedewa S. Market structures, socioeconomics, and tobacco usage patterns in Madagascar. Nicotine Tob Res. 2014;16(suppl 1):S56-S64. doi:10.1093/ntr/ntt020

6. World Health Organization. WHO report on the global tobacco epidemic, 2019: Country profile Madagascar. Accessed May 16, 2021. https://www.who.int/tobacco/ surveillance/policy/country_profile/mdg.pdf?ua=1

7. Veeranki SP, Mamudu HM, John RM, Ouma AE. Prevalence and correlates of tobacco use among school-going adolescents in Madagascar. J Epidemiol Glob Health. 2015;5(3):239-247. doi:10.1016/j.jegh.2014.12.005
CONFLICTS OF INTEREST

The authors have completed and submitted the ICMJE Form for Disclosure of Potential Conflicts of Interest and none was reported.

\section{FUNDING}

This research was aided by donors to Mada Clinics, Inc., a non-profit organization located at 4814 Willow Street Bellaire, Texas, USA 77401 whose mission is to fund the advancement of medical care and education for the underserved in rural Madagascar.

\section{ETHICAL APPROVAL AND INFORMED CONSENT}

The survey was approved by the Mayo Clinic IRB and Antsiranana Ministry of Health. Data were collected through a voluntary survey of visitors to a non-profit health clinic in the village of Maventibao.

PROVENANCE AND PEER REVIEW

Not commissioned; internally peer reviewed. 